\title{
Influence of irrigation of winter wheat by subirrigation method on the reclamation regime of lands
}

\author{
Aliakbar Khojiyev ${ }^{*}$, Mirzoolim Avliyakulov ${ }^{2}$, and Shakhnoza Khojiyeva ${ }^{3}$ \\ ${ }^{1}$ Tashkent institute of irrigation and agricultural mechanization engineers, Tashkent, Uzbekistan \\ ${ }^{2}$ Uzbekistan's cotton breeding, seed production and agrotechnologies research institute, Tashkent, \\ Uzbekistan \\ ${ }^{3}$ Tashkent pharmaceutical Institute, Tashkent, Uzbekistan
}

\begin{abstract}
Due to the rapid growth of the world's population and intensive economic development, the demand for natural resources, including water and land, is growing day by day. According to the UN, around the world, wheat is grown on an area of 217.71 million hectares, and at the same time, $6.4-7.8 \%$ of the total area is using the subirrigation method. The article presents the results of experiments on the widespread use of groundwater for irrigation of lands with a low level of groundwater and salinity of 1-3 $\mathrm{g} / \mathrm{l}$ in the conditions of meadow gray soils of the Syrdarya region.
\end{abstract}

\section{Introduction}

Scientific research aimed at improving the management of reclamation regimes in the world is of great importance. In this regard, it is important to develop new methods for the effective and targeted use of groundwater to increase the productivity of irrigated agricultural land and eliminate water shortages during the growing season. Effective ways to solve these problems are to meet the needs of agricultural crops in water at the expense of groundwater and to ensure moistening of the active soil layer based on the control of the water level in the ditches $[4,5,11,12,13,16,17]$.

In our country, including in the conditions of meadow gray soils of the Syrdarya region, the widespread use of groundwater for irrigation of lands with a low level of groundwater and salinity of 1-3 g/l helps to reduce water deficit during the growing season. Experimental work on the use of groundwater for irrigation of agricultural crops in the conditions of meadow gray soils of the Syrdarya region was carried out on the experimental fields of the farms of A. Khojaev, "Chinor" and "Baraka" of the Khavast district of the Syrdarya region $[1,2,3,6]$.

\footnotetext{
* Corresponding author: aliakbar-x@mail.ru
} 


\section{Methods}

In the experiments, the management of the reclamation regime of irrigated lands through the management of closed ditches, including sub-irrigation irrigation of winter wheat, was carried out in four replications; the variant area was $2500 \mathrm{~m}^{2}$ (length $50 \mathrm{~m}$, width $50 \mathrm{~m}$ ). Fragments in the plan were systematically arranged in four tiers (according to the level of groundwater) $[14,15,18,20]$.
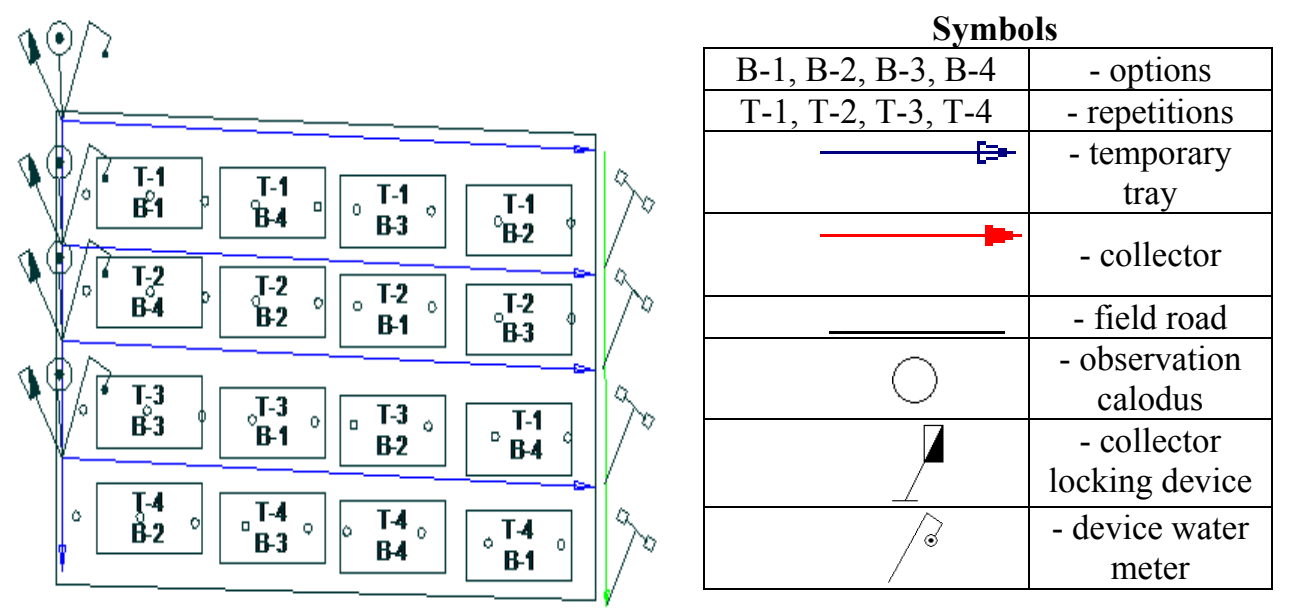

Fig-1. Experimental schemes for research sites.

Controlling the reclamation regime, the groundwater level was artificially raised to a depth of 1.0 and $2.0 \mathrm{~m}$ by blocking the main trenches. The active soil layer was moistened, and the previous soil moisture was maintained due to the rise of groundwater through the soil capillaries.

\section{Results and Discussion}

Studies have shown that at a groundwater level of 1,0 $\mathrm{m}$, with atmospheric precipitation of $2860-3540 \mathrm{~m}^{3} /$ ha, with an amount of irrigation water of $950-1150 \mathrm{~m}^{3} /$ ha, with an inflow of groundwater of $1562-1718 \mathrm{~m}^{3} / \mathrm{ha}$, evaporation into the soil and transpiration was 5015 $5287 \mathrm{~m}^{3} /$ ha, salinity per hectare $-6.7-7.6 \mathrm{t} / \mathrm{ha}$. Also, at a groundwater level of $2.0 \mathrm{~m}$, the amount of irrigation water is in the absence of atmospheric precipitation and evaporation and transpiration in the soil; the input of salts to the sown areas is 2.8-3.6 t/ha. Also, with a groundwater level of 3,0 meters, the amount of irrigation water is $2604-2624 \mathrm{~m}^{3} / \mathrm{ha}$, in the absence of an inflow of groundwater, in the absence of precipitation and evaporation and transpiration in the soil, the input of salts to the sown area is 3.3-4.1 $\mathrm{t} / \mathrm{ha}[1,3]$.

According to the results of a study based on the analysis of data on changes in the groundwater level in the fields sown with A. Khodjaev's winter wheat, in experiments conducted in October-January, in the absence of sub-irrigation irrigation, the water level in the experimental field of $1.0 \mathrm{~m}$ was controlled $274-287 \mathrm{~cm}$, the groundwater level was $267-$ $269 \mathrm{~cm}$ in the field of the controlled experiment of $2.0 \mathrm{~m}, 267-269 \mathrm{~cm}$ in the field of $2.0 \mathrm{~m}$ in the controlled variant of the experiment and $295-289 \mathrm{~cm}$ in the control variant, in February-June when using the subirrigation method, one can see that the water table rose from $249 \mathrm{~cm}$ to $90 \mathrm{~cm}$ in a controlled experimental field of 1,0 m and from $269 \mathrm{~cm}$ to 194 $\mathrm{cm}$ in a controlled experimental field of 2,0 $\mathrm{m}$ (Fig.-2). 


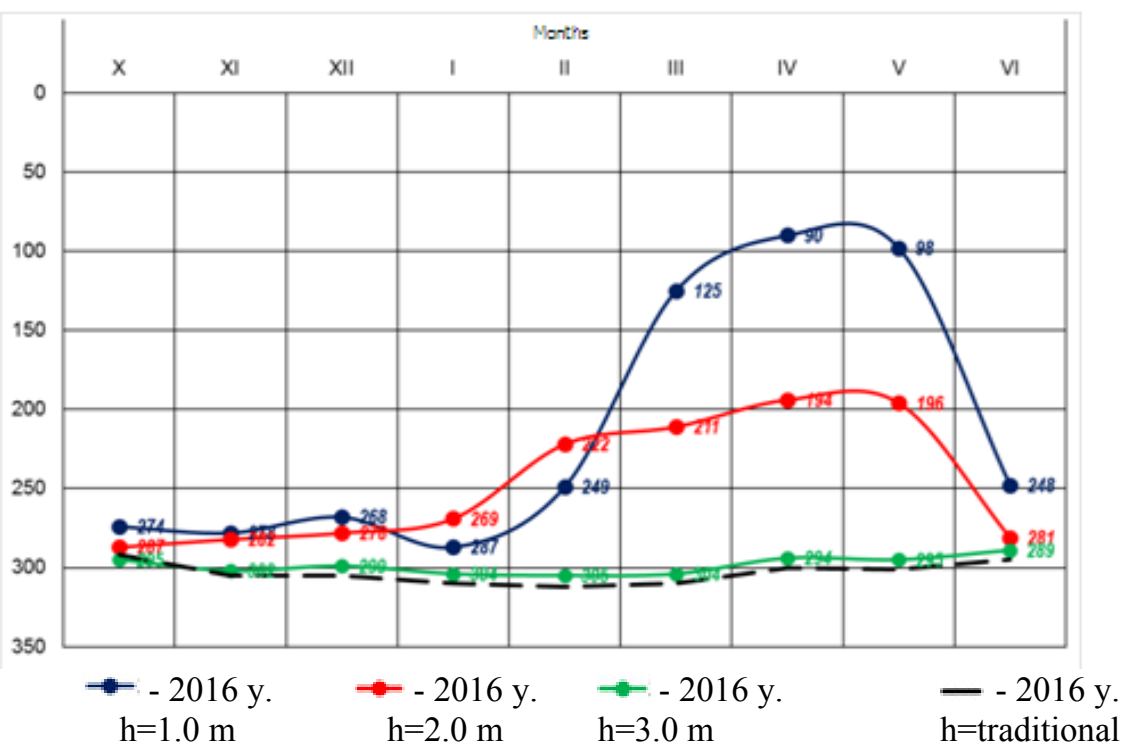

Fig-2. Dynamics of changes in the level of groundwater

According to the results of experiments on the effect of sub-irrigation irrigation on groundwater salinity in the experimental field of the farm of A. Khodjaev, with subirrigation irrigation, groundwater salinity in the experimental version with a groundwater level of $1,0 \mathrm{~m}$ in October-January was 2,82-2,93 g/l, we see that in February-June it was $3,12-4,64 \mathrm{~g} / \mathrm{l}$. Also, the groundwater level in a controlled experiment of 2,0 $\mathrm{m}$ was 2,90$3,08 \mathrm{~g} / 1$ in October-January and 3,08-4,50 g/l in February-June. In the control variant in October-January, it was 3.00-2.79 g/l, and in February-June - 3.04-4.43 g/l. (Figure 3).

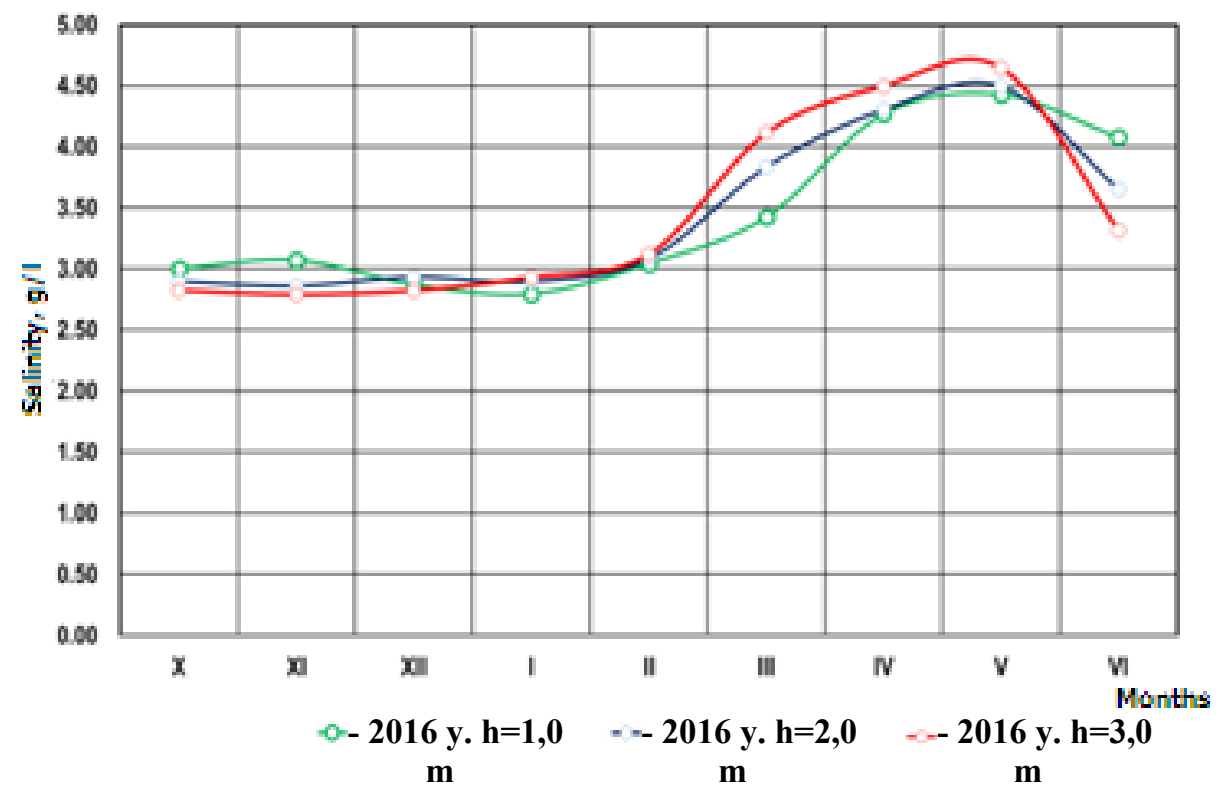

Fig-3. Dynamics of changes in groundwater salinity 
In general, according to the results of studying changes in the level and mineralization of groundwater in the experimental fields, the period of occurrence of deep groundwater in the experimental fields of A. Khodjaev's farm coincided with October-January, as well as with the growing season, i.e., from February to June, it was observed that the water table was close to the surface when the irrigation method was used $[1,2,4,5]$.

It was also noted that the mineralization of groundwater was higher in the experimental version, where the groundwater level was $1,0 \mathrm{~m}$ than in the experimental version, where the groundwater level was $2,0 \mathrm{~m}$. At the same time, no irrigation work was carried out in October-January, only a decrease in the mineralization of groundwater due to atmospheric precipitation and an increase in the mineralization of groundwater due to the flow of salts along the river as a result of irrigation works since February.

According to a study of the effect of the number of winter wheat irrigations on yield, the average yield was 23,0 q/ha with 2-3-fold irrigation in highly saline areas of the Chinor farm, $16 \mathrm{Ds} / \mathrm{m}$ according to FAO or $57 \%$ of the yield. The average yield was $38,8 \mathrm{q} / \mathrm{ha}$ with 3-4-fold irrigation in areas of moderate salinity of the Baraka farm with moderate salinity, which amounted to $8 \mathrm{Ds} / \mathrm{m}$ or $98 \%$ of the yield according to FAO. At the same time, on the slightly saline plots of A. Khojaev's farm, when sowing up to 5 times, the average yield was $62,0 \mathrm{q} / \mathrm{ha}$, according to FAO - $4 \mathrm{Ds} / \mathrm{m}$ or $100 \%$ of the yield, i.e., as a result of an increase in the number of sprinklers. A regularity of growth was observed.

At a groundwater level of $1.0 \mathrm{~m}$, the number of irrigations was 3 times; the irrigation rate was $950-1180 \mathrm{~m}^{3} / \mathrm{ha}$; at a groundwater level of 2 meters, the number of irrigations was 4 , the irrigation rate was $2200-2450 \mathrm{~m}^{3} / \mathrm{ha}$, at a groundwater level of 3 meters, the number of irrigations was 4 , the irrigation rate was $2580-2620 \mathrm{~m}^{3} /$ ha (Fig. 3).

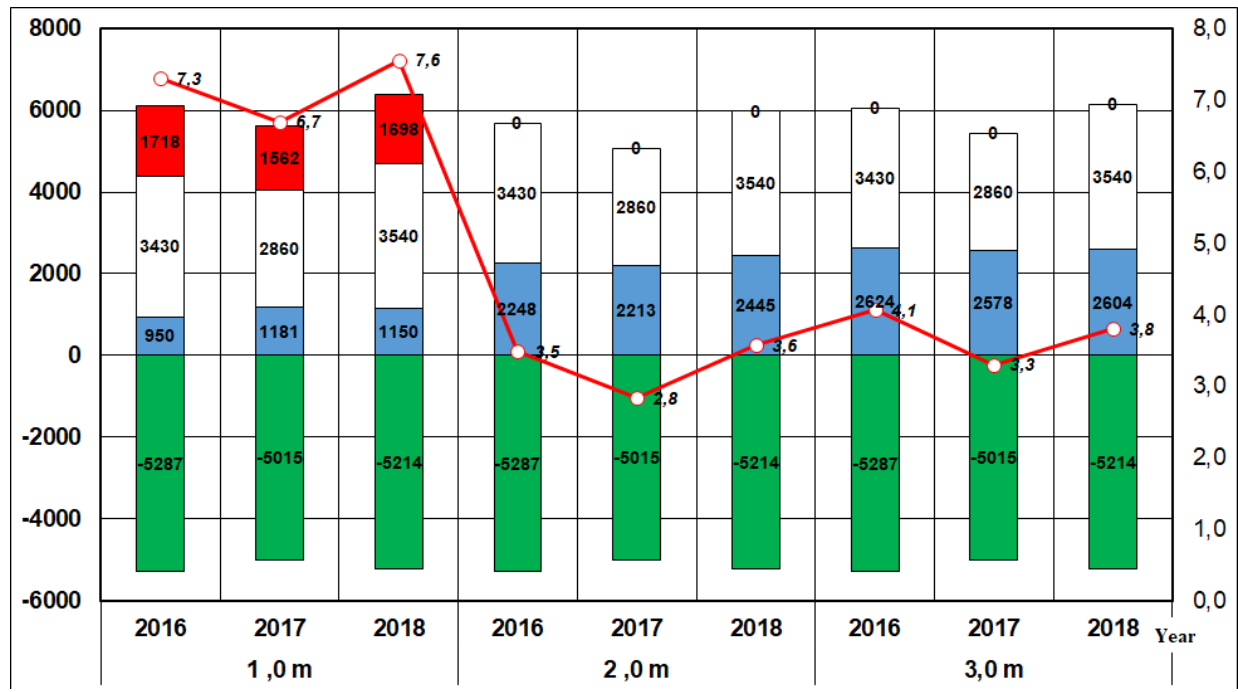

\footnotetext{
$\square$ - evaporation and transpiration, $\mathrm{m}^{3} / \mathrm{ha}$,

- - salt intake (by calculation), $\mathrm{t} / \mathrm{ha}$,

$\square$ - Groundwater inflow, $\mathrm{m}^{3} / \mathrm{ha}$

$\square$ - atmospheric precipitation, $\mathrm{m}^{3} / \mathrm{ha}$

$\square$ - Irrigation water amount, $\mathrm{m}^{3} / \mathrm{ha}$
}

Fig.3. Water-salt balance of winter wheat of the farm A. Khojaev

As can be seen from Figure 3, in the studies carried out during 2016-2018, when the groundwater level was 1,0 meter, atmospheric precipitation was $2860-3540 \mathrm{~m}^{3} / \mathrm{ha}$, the irrigation rate was $950-1150 \mathrm{~m}^{3} /$ ha, with the volume of groundwater inflow. 1562-1718 $\mathrm{m}^{3} /$ ha, the amount of evaporation and transpiration was $5015-5287 \mathrm{~m}^{3} /$ ha, the number of 
salts per 1 ha was $6,7-7,6 \mathrm{t} / \mathrm{ha}$. When the groundwater level was 2,0 $\mathrm{m}$, the vegetation rate was $2213-2248 \mathrm{~m}^{3} / \mathrm{ha}$, in the absence of an inflow of groundwater, with constant atmospheric precipitation and evaporation and transpiration of the inflow of salts to the cultivated areas, was not observed.

In the conditions of the groundwater level, $0 \mathrm{~m}$, when the amount of irrigation water 3 is $2604-2624 \mathrm{~m}^{3} / \mathrm{ha}$, in the absence of an inflow of groundwater, in the absence of atmospheric precipitation, as well as in the absence of evaporation and transpiration in the soil, the accumulation of salts in the cultivated areas does not was observed.

Figure 4 shows that in studies on the study of the salt balance of lands under winter wheat in the farm A. Khojaev according to the FAO method, showed that at the beginning of irrigation (groundwater level $3.0 \mathrm{~m}$ ) in the control variant, soil salinity was $2016-3.03$ $\mathrm{dS} / \mathrm{m}, 2017-3.16 \mathrm{dS} / \mathrm{m}$ and $2018-3.55 \mathrm{dS} / \mathrm{m}$. At the end of irrigation, soil salinity in the control variant (groundwater level $3.0 \mathrm{~m}$ ) was $3.30 \mathrm{dS} / \mathrm{m}$ - in 2016, $3.24 \mathrm{dS} / \mathrm{m}$ - in 2017 and $3.62 \mathrm{dS} / \mathrm{m}$ - in 2018.

In the experiment, soil salinity at the beginning of irrigation (groundwater level $2.0 \mathrm{~m}$ ) was $3.13 \mathrm{dS} / \mathrm{m}$ - in 2016, $3.16 \mathrm{dS} / \mathrm{m}$ - in 2017 and $3.2 \mathrm{dS} / \mathrm{m}$ - in 2018 year, and at the end of watering. soil salinity was, respectively, $3.26 \mathrm{dS} / \mathrm{m}$ - in 2016, $3.27 \mathrm{dS} / \mathrm{m}$ - in 2017 and $3.63 \mathrm{dS} / \mathrm{m}$ - in 2018 .

\section{Conclusions}

- $\quad$ in the experimental plots, the period of deep groundwater occurrence fell on OctoberJanuary and during the growing season, which falls on February-June; when using the subirrigation method, the groundwater level was close to the surface. In general, it was observed that the groundwater salinity was higher in the experimental version, where the groundwater level was $1.0 \mathrm{~m}$ than in the experimental version, where the groundwater level was $2.0 \mathrm{~m}$.

- on field experiments, it was determined that the annual volume of total evaporation (evapotranspiration) was in 2015-2016. - $528.7 \mathrm{~mm}, 2016-2017501.5 \mathrm{~mm}$ and 20172018 - $521.4 \mathrm{~mm}$, atmospheric precipitation was 324.4, 340.1 and $301.0 \mathrm{~mm}$, respectively. In water scarcity conditions, the best way to use groundwater for irrigation is to maintain their level at a depth of $1,0 \mathrm{~m}$ at a seasonal irrigation rate of $1094 \mathrm{~m} 3 / \mathrm{ha}$, but the salt content increases by $8,1 \mathrm{t} / \mathrm{ha}$ at the end of the growing season. The acceptable reclamation regime of groundwater consists of maintaining them at a depth of $2.0 \mathrm{~m}$ with an average seasonal irrigation rate of $2302 \mathrm{~m}^{3} / \mathrm{ha}$. Still, it was found that the salt content by the end of the growing season increases by 3.3 $\mathrm{t} / \mathrm{ha}$. Maintaining the groundwater level within $2.0 \mathrm{~m}$ makes it possible to reduce salt formation by $4.8 \mathrm{t} / \mathrm{ha}$.

\section{References}

1. Khojiyev A., Muradov R., Khaydarov T., Rajabov N., Utepov B. Some results of moisture and salt transfer in the initial period of plant development. International Journal of Engineering and Advanced Technology (IJEAT)/, Volume-9, pp 69076911. India, (2019).

2. Khojiev A., Muradov R. Moisture and salt transfer in the initial period of plant development. The path of science. International Journal, No. 8 (54), pp. 50-56. (2018).

3. Muradov R., Khojiev A. The optimal solution of leaching rates with a deficit of irrigation water. Agro Ilm Magazine, No. 5 (49), pp. 83-84. (2017).

4. Khamidov M.X., Suvanov B.U. Irrigation of crops by subirrigation//Monograph. 
Publishing house "UZBEKISTAN". pp.155 Tashkent. (2018).

5. Khamidov M.X., Isaev S.X. and others. The effect of subirrigation of cotton on hydromorphic soils on cotton yield // Journal of Irrigation and Land Reclamation. №2. pp.5 Tashkent, (2015).

6. Mirzoolim Avliyakulov, Normat Durdiev, Nurmamat Rajabov, Farruhjon Gopporov, Adkham Mamataliev. The changes of cotton seed-lint yield in parts of furrow length under different irrigation scheduling. Journal of Critical Reviews ISSN- 2394-5125 Vol 7, Issue 5, pp. 838-843. (2020),

7. Khojiyev A., Khaydarov T., Rajabov N., J.Pulatov. Optimal solution leaching rates with a deficit of irrigation water. IOP Conf. Series: Materials Science and Engineering 883 (2020) 012091, CONMECHYDRO - 2020.

8. Khojiyev A., Muradov R.A., Khaydarov T., J.Pulatov. Changes in the exchange of salt and moisture in groundwater management. IOP Conf. Series: Materials Science and Engineering 883 (2020) 012091, CONMECHYDRO - (2020).

9. Khojiyev A., Muradov R. Moisture and salt transfer in the initial period of plant development. The Way of Science. International scientific journal.Volgograd, № 8 (54) pp.50-54 (№5-Global Impact Factor. IF-0.543). Russia. (2018).

10. Z. Mirkhasilova, L. Irmuhamedova, S. Kasymbetova, G. Akhmedjanova M. Mirkhosilova. Rational use of collector-drainage water 2020 IOP Conf. Ser.: Mater. Sci. Eng. 883 012092. CONMECHYDRO 2020.

11. Saidhujaeva Nafisa, Nulloev Ulugbek, Mirkhasilova Zulfiya, Mirnigmatov Botir, Irmukhamedova Ludmila Production of Plant Product as a Process of Functioning Biotechnical System. IJEAT. ISSN: pp.2249-8958, Volume-9 Issue-1, October (2019).

12. Mirkhasilova Z.K. Ways to improve the water availability of irrigated lands. European science review No. pp.7-8 july-august, (2018)

13. Z. Mirkhasilova, L.Irmuhamedova G.Akhmedjanova, D. Tursunova. Transfer of vegetable water flows for full support of drained water from wells of vertical drainage. International journal of advanced research in science, engineering and technology. ISSN:2350-0328. Vol.6, Issue 5, pp. 9424-94262. May (2019).

14. Khamidov M., Matyakubov B., Isabaev K. "Substantiation of cotton irrigation regime on meadow-alluvial soils of the Khorezm oasis" // Journal of Critical Reviews, ISSN2394-5125, Volume 7, Issue 4, - pp. 347 - 353. (2020).

15. Matyakubov B., Begmatov I., Raimova I., Teplova G. "Factors for the efficient use of water distribution facilities"// CONMECHYDRO - (2020), IOP Conf. Series: Materials Science and Engineering 883 (2020) 012050 doi:10.1088/1757899X/883/1/012050.

16. Matyakubov B., Mamazhonov M., Teplova G, Shakirov B., Shakirov B. "Forebays of the poligonal cross - section of the irrigating pumping station"// CONMECHYDRO (2020), IOP Conf. Series: Materials Science and Engineering 883 (2020) 012050 doi:10.1088/1757-899X/883/1/012050.

17. Matyakubov B. How efficient irrigation can ensure water supply in the Lower Amudarya basin of Uzbekistan. International Water and Irrigation, 23 (3), pp. 26-27. (2003).

18. Hamidov, A., Khamidov, M., Ishchanov, J. Impact of climate change on groundwater management in the northwestern part of Uzbekistan.Agronomy, 10(8), 1173. (2020).

19. Khamidov, M.K., Khamraev, K.S., Isabaev, K.T. Innovative soil leaching technology: A case study from Bukhara region of Uzbekistan. IOP Conference Series: Earth and Environmental Science, 422(1), 012118. (2020), 
20. Khamidov, M., Khamraev, K., Azizov, S., Akhmedjanova, G. Water saving technology for leaching salinity of irrigated lands: A case study from Bukhara region of Uzbekistan. Journal of Critical Reviews, 7(1), pp.499-509. (2020). 